\title{
Functional consequences of Caribbean coral reef habitat degradation
}

\author{
Alice E. Webb ${ }^{1}$, Didier M. de Bakker ${ }^{2,3}$, Karline Soetaert ${ }^{4}$, Tamara da Costa $^{1}$, Steven M. A. C. van
} Heuven $^{5}$, Fleur C. van Duyl ${ }^{2}$, Gert-Jan Reichart ${ }^{1,6}$, Lennart J. de Nooijer ${ }^{1}$

${ }^{1}$ Department of Ocean Systems, NIOZ Royal Netherlands Institute for Sea Research, Den Hoorn, The Netherlands

$5{ }^{2}$ Department of Marine Microbiology and Biogeochemistry, NIOZ Royal Netherlands Institute for Sea Research, Den Hoorn, The Netherlands

${ }^{3}$ Wageningen Marine Research, Wageningen University and Research, Den Helder, The Netherlands

${ }^{4}$ Department of Estuarine and Delta Systems, NIOZ Royal Netherlands Institute for Sea Research, Yerseke, The Netherlands

${ }^{5}$ Groningen University, Faculty of Science and Engineering, Groningen, The Netherlands

$10 \quad{ }^{6}$ Department of Earth Sciences, Utrecht University, Utrecht, The Netherlands

Correspondence to: Alice E. Webb (webbea4@gmail.com)

\begin{abstract}
Coral reefs are declining worldwide. The abundance of corals has decreased alongside the rise of filter feeders, turf and algae in response to intensifying human pressures. This shift in prevalence of functional groups alters the biogeochemical processes in tropical water ecosystems, thereby influencing reef biological functions. An urgent challenge is to understand the

15 functional consequences of these shifts in order to develop suitable management strategies that aim at preserving the biological functions of reefs.
\end{abstract}

Here, we quantify biogeochemical processes supporting key reef functions (i.e. net community calcification (NCC) and production (NCP), and nutrient recycling) in situ for five different benthic assemblages currently dominating shallow degraded Caribbean reef habitats. To this end, a custom made tent was placed over communities dominated by either one of five

20 functional groups: coral, turf and macroalgae, bioeroding sponges, cyanobacterial mats or sand, to determine chemical fluxes between these communities and the overlying water, during both day and night. Measured fluxes were then translated into responsible biogeochemical processes by solving a system of differential equations describing the contribution of each process to the measured chemical fluxes. Estimated processes are low compared to those known for reef flats worldwide. No real gain in primary habitat is recorded, with negative or very modest net community calcification rates by all communities. Similarly, net production of biomass through photosynthesis is relatively low during the day and remineralisation of organic matter at night is relatively high in comparison, resulting in net heterotrophy over the survey period by most communities. Estimated recycling through nitrification and denitrification are high but denitrification does not fully counterbalance nutrient release from aerobic mineralisation, rendering all substrates sources of nitrogen. A multivariate pairwise analysis revealed that there is no significant difference between processes occurring on any of the assemblages, suggesting functional homogenisation 30 between distinct substrate types. We infer that the amount and type of organic matter released by abundant algal turfs and cyanobacterial mats on this reef, likely enhances heterotroph activity, and stimulates the proliferation of less diverse copiotrophic microbial populations, rendering the studied reef net heterotrophic and the overall biogeochemical 'behaviour' similar regardless of substrate type. 
https://doi.org/10.5194/bg-2021-64

Preprint. Discussion started: 23 March 2021

(c) Author(s) 2021. CC BY 4.0 License.

(c) (i)

\section{Introduction}

35 Community composition and biodiversity across all kinds of ecosystems are responding to escalating anthropogenic activities (McGill et al. 2015). In both terrestrial and aquatic systems, climate change, pollution and habitant fragmentation have promoted the expansion of opportunistic and tolerant species and the elimination of more sensitive yet key specialists (Clavel et al. 2011). The latter has resulted in the increased similarity of biological communities within ecosystems and across spatial scales (Burman et al. 2012; Cramer et al. 2021). This is worrisome as it may lead to a decrease in functional diversity therefore

40 limiting services provided by biological communities (Matsuzaki et al. 2013; White et al. 2018). Furthermore, this functional homogenisation may synchronise the biological response to new or intensified anthropogenic pressures across local communities thus reducing resilience of metacommunities (Tobias and Monika, 2012; Sonnier et al. 2014; Petsch et al. 2020). Coral reefs support immense biodiversity and provide important ecosystem services to millions of people (Moberg and Folke, 1999). They are however in global decline as they are experiencing major loss in coral abundance and shifts in species

45 composition in response to increasing human pressures and accelerating rates of environmental and climate change (Koop et al. 2001; Langdon and Atkinson, 2005; Andersson and Gledhill, 2013; De'ath et al. 2012; Chen et al. 2015). Returning degraded reefs to their original state is, in many cases, no longer an option (Hughes et al. 2017). Instead, today's challenge is to guide coral reefs through this transition while identifying and securing the ecosystem services that highly altered reef assemblages can provide to people in the future (Oliver et al. 2015). Therefore, it is essential to understand and quantify the

50 functional consequences of community changes on increasingly degraded coral reefs.

The depauperate reef systems in the Caribbean, have, since the early 1970s, undergone considerable reorganisation with regards to community composition and structural appearance (Gardner et al. 2003; Jackson et al. 2014). The communities encountered on these reefs bear little resemblance to the systems once dominated by reef building Acropora spp. and Orbicella spp. (van Duyl, 1985; Alvarez-Filip et al. 2009). Major declines in the abundance of species such as Acropora palmata and

55 Acropora cervicornis severely compromised reef function as these species was the main representatives of critical functions including carbonate accretion, productivity and structural complexity. Low functional redundancy on Caribbean reefs, i.e. the reduced capacity of one or more species to functionally compensate for the loss of another, makes them particularly vulnerable to functional homogenisation (McWilliam et al., 2018). Instead, algal turf assemblages and macroalgae, excavating sponges, cyanobacteria, rubble and sand have increased, thereby mirroring the decrease in stony corals (Aronson et al. 2005; Burman

60 et al. 2012; Cramer et al. 2021). Although changes in community composition are well documented as they can be followed by monitoring the coverage of the various benthic taxa over time (Barott et al. 2012; de Bakker et al. 2016; de Bakker et al. 2017), assessing the impact of these shifts on the community ecophysiology in situ has proven more challenging.

The keystones of coral reef functioning include provision of a structural habitat through carbonate deposition, production and assimilation of biomass produced through photosynthesis and efficient cycling of nutrients within the ecosystem (Brandl et al.

65 2019). The biogeochemical processes that underlie these key functions are primary production, aerobic mineralisation, calcification, bioerosion, and nutrient release/uptake. Complementary to conventional monitoring efforts, quantification of the 
https://doi.org/10.5194/bg-2021-64

Preprint. Discussion started: 23 March 2021

(c) Author(s) 2021. CC BY 4.0 License.

(c) (i)

net budgets of these processes will provide insight into how reef degradation and community reorganisation affect reef functioning (Brandl et al. 2019). Presently, efforts to quantify community functions have focused on individual functional groups (Brocke et al. 2015, 2018; den Haan et al. 2016; Webb et al. 2017; de Bakker et al. 2018) and the limited amount of

70 studies that incubated whole communities in situ have so far not accounted for the complexity of interactions between biogeochemical processes (Yates and Halley, 2003, Kline et al. 2012, van Heuven et al. 2018, Roth et al. 2020).

Here, biogeochemical processes underlying key reef functions were quantified in situ across five different benthic assemblages found on the fringing reef of Curaçao, with functional groups that currently characterise many degraded shallow reef habitats throughout the wider Caribbean. To this end, a custom-made tent was placed over substrates dominated by either 1) coral, 2)

75 turf and macroalgae, 3) bioeroding sponges, 4) benthic cyanobacteria mats or, 5) sand. Chemical fluxes between water column and reef were then determined by monitoring nutrients, inorganic carbon chemistry and oxygen. This was done both during the day and night to estimate overall net metabolism of these communities. To account for the multidimensionality of processes interacting on the measured variables, the change in their concentrations is related to the responsible metabolic processes by solving a system of ordinary differential equations that describe the contribution of each process to the measured chemical

80 fluxes. With this approach, we aim to provide accurate estimates of biogeochemical processes that underlie functions of the newly configured shallow Caribbean reefs.

\section{Materials and Methods}

\subsection{Study Site}

Reef incubations were carried out on the leeward side of Curaçao (Piscadera Bay; 1207'16.3"N 68 $58^{\prime} 13.2^{\prime \prime} \mathrm{W}$ ) between

85 February 12th and March 22th 2018, at depths ranging from 5 to 7 meters. The water at the study site is characterised by episodes of high turbidity and is periodically eutrophied due to terrestrial runoff and ineffective waste-water treatment. Sediment plumes transporting high concentrations of nitrate, ammonium and phosphate into the shore's fringing reef are commonly encountered after a period of heavy rainfall (den Haan et al. 2016). The shallow reef flat nearby the entrance of the bay in which we conducted our incubations is characterised by rubble and patchy distribution of small coral heads making this

90 location particularly suitable for the deployment of tent incubations.

\subsection{Tent Incubations}

The incubation enclosure consists of a custom made, tetrahedron-shaped "tent" (Fig. 1). It has transparent, vinyl-and-butanyl walls with rigid pole edges of $1 \mathrm{~m}$, resembling the cBIT described by Haas et al. (2013). It also includes $0.5 \mathrm{~m}$ long flaps extending outward from each of the tent's three sides, allowing for proper sealing of the tent to the substrate by placing weights on the flaps. It covers a $0.43 \mathrm{~m}^{2}$ planar surface, and encloses a $118 \mathrm{~L}$ volume. All three sides of the tent contained an opening to allow flushing of the enclosed volume between incubations: during incubations these openings were sealed. Water enclosed in the incubation tent was homogenised during the experiment by means of a continuously running brushless submergible 
https://doi.org/10.5194/bg-2021-64

Preprint. Discussion started: 23 March 2021

(c) Author(s) 2021. CC BY 4.0 License.

(c) (i)

water pump (BLDC pump Co., Ltd.). This pump was attached to one of the tent poles, at half the height of the tent, generating a vertical circulating turbulence, while minimising stirring up of sediment. Effectiveness of the stirring was demonstrated by rapid and even dispersal of a small dose of injected fluorescein prior to the incubation. Surge movement was retained due to the non-rigid texture of the tent walls. Five different types of substrate dominated either by turf and macroalgae, sand, bioeroding sponges, benthic cyanobacteria mats or coral (Fig. 2) were incubated both during daytime (in triplicates) and at night-time (in duplicates) for 4 hours each.

\subsection{Substrate Compositions}

105 Substrates dominated by either coral, turf and macroalgae (TMA), bioeroding sponges (BES), cyanobacteria mats (BCM), or sand were incubated (Fig. 2). Three reef patches of each reef assemblage were chosen depending on their dominant benthic component (see Table S1 for detailed species composition and cover). In some cases, to fit adequate incubation location and the tent capacity, pieces of rubble infested with sponge or covered in turf were added or retrieved from the community to be incubated. Incubated substrate included colonised hard substrate surrounded by bare hard substrate covered in a fine layer of

110 sand for better enclosure deployment (except for sand incubations). The incubated coral species are characteristic of degraded Caribbean reefs and include some of the most prominent tolerant and opportunistic species found on modern reefs (Darling et al. 2012; de Bakker et al. 2016; Cramer et al. 2021) (see Table S1). Turf here refers to epilithic algal matrix defined by Clements et al. (2016) as 'a conglomeration of short, turf-forming filamentous algae ( $<1 \mathrm{~cm}$ high), macroalgal spores, microalgae, sediment, detritus and associated fauna'. The benthic cyanobacterial mats in all three tent replicates were thick brown/reddish

115 in colour and in line with the description in Brocke et al. (2018) for mats found between 3 and 7 meters dominated by the species Oscillatoria bonnemaisonii. Percentage cover was measured in situ after removal of the tent. For substrates dominated by coral, its cover ranged from 34 to $36 \%$. Turf and macroalgae cover ranged between 72 to $83 \%$, bioeroding sponge cover varied from 38 to $40 \%$, and cyanobacterial mats cover ranged from 83 to $91 \%$ (Fig. 2).

\subsection{In Situ Measurements}

120 Measurements of salinity $(\mathrm{S})$, temperature $(\mathrm{T})$, dissolved oxygen $\left(\mathrm{O}_{2}\right)$ and photosynthetically active radiation (PAR) within the tent were recorded at $1 \mathrm{~min}$ intervals throughout the duration of the incubations. $\mathrm{S}$ and $\mathrm{T}$ were measured using a Star-Oddi DST CTD, $\mathrm{O}_{2}$ was recorded using a HOBO U26 dissolved oxygen sensor and data logger and PAR was assessed by an Odyssey light logger (Dataflow Systems PTY Ltd., Christchurch, NZ), calibrated in air against Walz instrument (Walz ULM500, Walz GmbH, Effeltrich, Germany). In addition, S, T and PAR were measured for the duration of the incubations outside the tent using the same sampling frequency. All instruments within the tent were attached to the three ridges except the Odyssey logger which was placed on the substrate facing upwards (covering approximately $150 \mathrm{~cm}^{2}$ of the substrate). 
https://doi.org/10.5194/bg-2021-64

Preprint. Discussion started: 23 March 2021

(c) Author(s) 2021. CC BY 4.0 License.

(c) (i)

\subsection{Discrete Sampling}

During each incubation, discrete samples both inside and outside the tent were collected at $\mathrm{T}_{0}$, after $2\left(\mathrm{~T}_{2}\right)$ and after 4 hours $\left(\mathrm{T}_{4}\right)$ by scuba diving for the analyses of total alkalinity $\left(\mathrm{A}_{\mathrm{T}}\right)$, total inorganic carbon $\left(\mathrm{C}_{\mathrm{T}}\right)$ and nutrients. $\mathrm{pH}$ was calculated from

130 the former two parameters using the package Seacarb (Lavigne et al. 2009). Sampling of the tent interior was carried out from the outside by drawing seawater through $150 \mathrm{ml}$ plastic syringes connected to a $1.5 \mathrm{~m}$ gas-impermeable tube (Tygon; Fig. 1). Syringes were flushed three times with the sampling water before collecting an actual sample. The tubing was fixed around a rigid edge of the tent in such way that the seawater was sampled from the centre of the tent incubation. The tube end located inside the tent was equipped with a Whatman ${ }^{\circledR}$ filter $(\mathrm{G} / \mathrm{F} 0.47 \mu \mathrm{m})$.

135 Analyses for $\mathrm{A}_{\mathrm{T}}$ were performed within 2 hours upon sampling using spectrophotometrically guided single-step acid titration (Liu et al. 2015) and samples for $\mathrm{C}_{\mathrm{T}}$ were run on an autoanalyser Traacs 800 spectrophotometric system (Stoll et al. 2001). Accuracy of both instruments was set using certified reference material supplied by Scripps Institute of Oceanography (Dickson et al. 2007). Precision of replicates was $2.7 \mu \mathrm{mol} \mathrm{kg}{ }^{-1}$ for CT and $0.9 \mu \mathrm{mol} \mathrm{kg}^{-1}$ for $\mathrm{A}_{\mathrm{T}}$. Samples for dissolved inorganic macronutrients $\left(\mathrm{NO}_{2}+\mathrm{NO}_{3}, \mathrm{NO}_{2}, \mathrm{PO}_{4}\right.$ and $\left.\mathrm{NH}_{4}\right)$ were prepared by dispensing sampled water through $0.8 / 0.2 \mu \mathrm{m}$

140 Acrodisk filters into $5 \mathrm{ml}$ pony vials, and subsequently stored at $-20^{\circ} \mathrm{C}$ until analysis at NIOZ on a QuAAtro continuous flow analyser (SEAL Analytical, GmbH, Norderstedt, Germany) following GO-SHIP protocol (Hydes et al. 2010).

\subsection{Rates of Water Exchange}

After sampling water at $\mathrm{T}_{0}$ for $\mathrm{A}_{\mathrm{T}}, \mathrm{C}_{\mathrm{T}}$ and nutrients, $450 \mathrm{ml}$ of water saturated in salt was injected into the tent. The rate at which the elevated interior salinity equilibrates with ambient salinity during the incubation is used to estimate the rate of water exchange with the surrounding sea water for each incubation.

The rate of change of salinity within the incubation can be solved by the differential equation below:

$$
\frac{d S}{d t}=K(\text { Sout }-S)
$$

Where $\frac{d s}{d t}$ is the rate at which salinity changes within the tent, Sout is the exterior salinity, $\mathrm{S}$ is the interior salinity and $\mathrm{K}$ is the water exchange rate.

150 The equation is solved using the function 'ode', within the package deSolve (Soetaert et al. 2010), the R routine that solves the differential equations. Function 'modfit' from the package FME (Soetaert and Petzoldt, 2010) was used to perform iterative minimisation (based on least squares) on residuals to find best fit within lower and upper bounds.

\subsection{Inverse Modelling and Model-Data Comparison}

We can describe the mathematical "state" of the incubation's dynamic system based on the mass balance of the measured

155 variables. The five differential equations depicted below relate the change in their concentrations to the responsible processes, which are assumed to have remained constant over time. 
https://doi.org/10.5194/bg-2021-64

Preprint. Discussion started: 23 March 2021

(c) Author(s) 2021. CC BY 4.0 License.

\section{(c) (1)}

Since the involved processes affect the different chemical components simultaneously, the combination of these differential equations can be used to solve the contribution of the processes to the observed changes. The processes of interest include aerobic mineralisation $\left(\mathrm{O}_{2}\right.$ consumption related to mineralisation), primary production (PP), calcification, dissolution, nitrification and denitrification.

$\frac{d C_{T}}{d t}=$ mineralisation $-P P-$ calcification + dissolution $+K\left(C_{T}\right.$ out $\left.-C_{T}\right)$

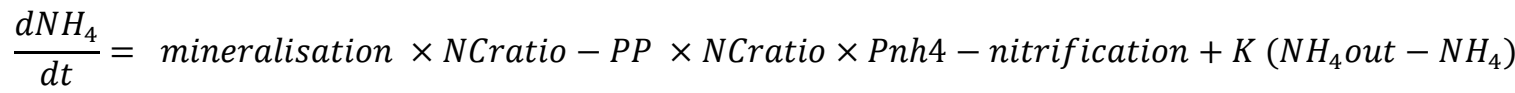

$\frac{d \mathrm{NO}_{3}}{d t}=-($ mineralisation $\times p$ Deni $\times 0.8)-P P \times N C_{\text {ratio }} \times(1-P n h 4)+$ nitrification $+\mathrm{K}\left(\mathrm{NO}_{3}\right.$ out $\left.-\mathrm{NO}_{3}\right)$

$165 \frac{d A_{T}}{d t}=-2 \times$ calcification $+2 \times$ dissolution $+\frac{d N H_{4}}{d t}-\frac{d N O_{3}}{d t}+K\left(A_{T}\right.$ out $\left.-A_{T}\right)$

$\frac{d \mathrm{O}_{2}}{d t}=-$ mineralisation $\times O C_{\text {ratio }} \times(1-p$ Deni $)+P P \times O C_{\text {ratio }}-2 \times$ nitrification $+K\left(\mathrm{O}_{2}\right.$ meanout $\left.-\mathrm{O}_{2}\right)$

With mineralisation describing the degradation of an organic compound to its mineral components, i.e. carbon dioxide and inorganic nutrients. PP is the primary production and calcification is the deposition of calcium carbonate. Pnh4 is the part of

$170 \mathrm{~N}$ uptake as $\mathrm{NH}_{4}$ for primary production. Dissolution results in an increase of calcium and carbonate ions by degradation of calcium carbonate shells and/or skeletons and $\mathrm{K}$ is the water exchange rate. Nitrification is the process by which ammonium $\left(\mathrm{NH}_{4}{ }^{+}\right)$is converted into nitrate $\left(\mathrm{NO}_{3}^{-}\right)$; two moles of oxygen are needed to oxidize one mole of ammonium during nitrification. pDeni is the fraction of mineralisation that respires nitrate (i.e. denitrification). The $\mathrm{OC}_{\text {ratio }}$ is the ratio between the concentrations of oxygen and $\mathrm{C}_{\mathrm{T}}$. The $\mathrm{NC}_{\text {ratio }}$ is the ratio between $\mathrm{N}$ and $\mathrm{C}_{\mathrm{T}}$. The 0.8 constant refers to the denitrification redox

175 reaction (Soetaert et al. 2007).

We start by determining the parameters that can be fitted, based on parameter collinearity. After producing a best-fit set of the selected parameters, we quantify parameter uncertainty, and produce sensitivity ranges around the modelled variables.

The $\mathrm{OC}_{\text {ratio }}, \mathrm{NC}_{\text {ratio }}$ and $\mathrm{K}$ parameters are always fixed and estimated from data prior to running the model. Others vary between fixed and free (to be fitted) depending on collinearity and light. For instance, primary production is fixed at 0 during night incubation, however during the day, only the dominant process can be estimated. Some parameters are highly correlated with each other such as primary production and remineralisation or calcification and dissolution and therefore cannot be estimated simultaneously. In general, when the collinearity index exceeds 20 , the linear dependence is assumed to be critical (i.e. it will be impossible or difficult to estimate all the parameters in the combination together).

Collinearity of the parameter sets is measured using function 'collin' within the FME package (Soetaert and Petzold, 2010).

185 The model equations are specified in a function that calculates the rate of change of the state variables $\left(\mathrm{dC}_{\mathrm{T}}, \mathrm{dNH}_{4}, \ldots\right)$. Input to the function are the model time $(t)$, the values of the state variables $\left(\mathrm{C}_{\mathrm{T}}, \mathrm{NH}_{4}, \mathrm{NO}_{3}, \mathrm{~A}_{\mathrm{T}}\right.$ and $\left.\mathrm{O}_{2}\right)$ and the parameters 
https://doi.org/10.5194/bg-2021-64

Preprint. Discussion started: 23 March 2021

(c) Author(s) 2021. CC BY 4.0 License.

(c) (i)

(remineralisation, calcification, etc.). The differential equation model is solved using function 'ode', within the package deSolve, the $\mathrm{R}$ routine that solves the differential equations.

The discrepancy of the model solution with observed changes within the tents is calculated using function 'modCost' still in the FME package which estimates the residuals and the variable and model costs (sum of squared residuals).

Function 'modfit' was then used to perform iterative minimisation (based on least squares) on residuals to find the parameter giving the best fit within lower and upper bounds. Estimated parameters are the unknown fluxes (mineralisation, PP, calcification, etc.).

\subsection{Conversion to fluxes}

195 The best-fit parameters, i.e. the input rates $\mathrm{R}$ (in $\mu \mathrm{mol} \mathrm{kg}^{-1} \mathrm{~min}^{-1}$ ), in the tent are converted to fluxes from the water-substrate interface $\left(\mathrm{mmol} \mathrm{m}^{-2} \mathrm{~h}^{-1}\right)$, assuming an enclosed mass of water of $108 \pm 10 \mathrm{~kg}$ (tent encloses approximately 118 litres of volume; of which substrate volume is $\sim 10 \mathrm{~L}$; seawater density $\sim 1022 \mathrm{~kg} \mathrm{~m}^{-3}$ ) and an incubated planar surface of $0.43 \mathrm{~m}^{2}$.

Net community calcification (NCC) fluxes were determined from the sum of predicted calcification and dissolution. The model captures the dominant net flux and does not distinguish the relative contributions of gross calcification and dissolution to the integrated NCC rate. Net community production (NCP) is the difference between remineralisation and primary production. Denitrification is estimated by multiplying pDeni and mineralisation parameters together.

\subsection{Statistics}

To assess the differences between the effects of community composition on biogeochemical processes, we ran a nonparametric permutational multivariate analysis of variance (PERMANOVA) with pairwise contrasts. The vegan Package in $R$

205 (Oksanen et al. 2007) was used to calculate a dissimilarity matrix using Euclidian distance. The Holm-Bonferroni method was used to adjust the rejection criteria for each of the individual hypotheses and therefore reduce the higher probability of obtaining Type I errors (false positives) when performing multiple comparisons (Holm, 1979).

\section{Results}

In-tent light and temperature were only slightly impacted by the tent enclosure compared to the exterior (Fig. 3). Light was on

210 average $17 \%$ lower inside than outside the tent and changes in temperature were dampened within the tent. In-tent temperatures were on average $0.2^{\circ} \mathrm{C}$ higher than those outside the tent.

Application of Equation (1) to salinity data collected during all incubations yields leak rates $\mathrm{K}$ of the enclosure $\mathrm{f}$ ranging between 0.004 and $0.044 \mathrm{~min}-1$. This indicates that 0.5 to $4.8 \mathrm{~kg}$ of seawater (i.e., $\mathrm{K} \times 108 \mathrm{~kg}$ ) is exchanged every minute between the incubation enclosure and the environment. These rates correspond to the intensity of the water movement observed

215 and recorded visually at the time of each incubation. Fig. 4 shows the data used to estimate the rate of water exchange of an incubation with relatively minor leakage (A) and one where leakage is more severe (B). In these examples, in-tent salinity 
https://doi.org/10.5194/bg-2021-64

Preprint. Discussion started: 23 March 2021

(c) Author(s) 2021. CC BY 4.0 License.

(c) (i)

returns to ambient concentrations after $\sim 1$ and $\sim 2$ hours respectively. The dilution rate $\mathrm{K}=0.0192$ and $\mathrm{K}=0.0751$ indicate that these particular tents leaked at a rate of 2.1 to $8.1 \mathrm{~kg}$ of seawater per minute.

The model shows a relatively good fit to the observations, indicating that the interactions between processes and their effects on chemical fluxes were considered correctly (Fig. S1). Overall fit is usually better on night data, which is mostly due to the inability of the model to predict irregular oxygen evolution during the day-time (Table S2). Graphic output of two incubations for the model employed to estimate reef processes are presented in Fig. 5. Output for all incubations, are listed in the supplement (Fig. S1, as well as all parameter predictions and their significance in Table S2).

As the process estimates are limited to net increase or decrease, fluxes for PP and mineralisation are presented as net community production (NCP) and calcification and dissolution are combined into net community calcification (NCC; Fig. 6; Table 1).

NCP shows a clear diurnal pattern (Fig. 6). While all NCP values are modestly skewed towards net autotrophy during the day (except for sand), the strongest signal is found for substrates dominated by BCMs with an average daily NCP of $5.6 \mathrm{mmol} \mathrm{m}$ ${ }^{2} \mathrm{~h}^{-1}$. Night values indicate net respiration ranging from an average of $-2.64 \mathrm{mmol} \mathrm{m}{ }^{-2} \mathrm{~h}^{-1}$ on substrates dominated by TMA to

$230-16.28 \mathrm{mmol} \mathrm{m}^{-2} \mathrm{~h}^{-1}$ on substrates dominated by bioeroding sponges.

A clear diurnal signal also resides in NCC fluxes for all substrates involved (Fig. 6). Most NCC fluxes recorded during daytime (with the exception of sand incubations) indicate net $\mathrm{CaCO}_{3}$ precipitation. At night, most NCC fluxes indicate net $\mathrm{CaCO}_{3}$ dissolution, especially on substrates dominated by BES and BCMs. The absence of change in $\mathrm{A}_{\mathrm{T}}$ for coral dominated substrates during the night indicates that dissolution equals calcification during these incubations and hence, the average NCC is close to

2350 . Substrates dominated by coral generated the strongest decrease in $\mathrm{A}_{\mathrm{T}}$ (net precipitation) during daytime, yielding an average $\mathrm{NCC}$ rates of $0.45 \mathrm{mmol} \mathrm{CaCO}_{3} \mathrm{~m}^{-2} \mathrm{~h}^{-1}$. Highest net dissolution was found at night-time for incubations of substrates dominated by bioeroding sponges and cyanobacterial mats, with a similar average of 0.56 and $0.63 \mathrm{mmol} \mathrm{CaCO}_{3} \mathrm{~m}^{-2} \mathrm{~h}^{-1}$ respectively. All average fluxes and respective 95\% confidence intervals are listed in Table 1.

Nitrification was found to occur predominantly at night with higher fluxes in incubations of substrates dominated by bioeroding

240 sponges, cyanobacterial mats and corals. Denitrification also occurred mostly at night except on sand where daytime and nighttime fluxes were small but relatively similar (Fig. 6).

The pairwise perMANOVA results revealed that there were no significant differences in processes measured between any communities with distinct composition (Table S3). R-squared values varied from 0.05 to 0.17 indicating that 5 to $17 \%$ of the variation in distances is explained by the grouping being tested (here for BCM vs BES ( $p=0.691$ and BCM vs sand ( $p=0.304$ respectively). The differences between day and night processes were significant $\left(\mathrm{R}^{2}=0.43, p=0.001\right)$.

\section{Discussion}

The biogeochemical flux assessment has enabled us to identify and quantify the biological functions that are currently at play of this degraded Curaçaon reef. Although the present study only investigated the shallow part of one single reef, it gives us 
https://doi.org/10.5194/bg-2021-64

Preprint. Discussion started: 23 March 2021

(c) Author(s) 2021. CC BY 4.0 License.

\section{(c) (i)}

insight into the dire effects that shifts in coral species and functional groups has had on the overall functioning of these communities. Comparison with coral reefs in different biogeographical context is needed to establish whether the rates obtained here are site-specific or representative of degrading Caribbean coral reefs in general.

The shallow reef communities investigated here barely support reef functions that are usually ascribed to a healthy coral reef. Overall, net community calcification and production on these substrates are low compared to reef flats worldwide (Atkinson, 2011). No significant gain in primary habitat is recorded with very low or negative net community calcification rates on all substrates. Net production and therefore accumulation of biomass produced through photosynthesis is also low, while heterotrophic processes are prominent. Recycling processes, nitrification and denitrification, are high but do not prevent net nutrient release from aerobic mineralisation, rendering all substrates, sources of nitrogen. Although processes recorded on substrates dominated by coral, bioeroding sponges and cyanobacterial mats show some variation between types of substrates, the overall performance of complementary processes for each of these assemblages is relatively comparable. In addition to the modest biological functions of these benthic communities - resulting from low net community calcification and production results suggest that some degree of functional homogenisation is occurring between substrates dominated by different functional groups.

\subsection{Net Dissolving Reef}

Although net calcification was recorded during the day on all substrate types (except sand), it did not compensate for higher dissolution rates at night except on substrates dominated by coral. Diel shifts between net calcification and net dissolution are not uncommon and have been recorded on healthier reefs than the one studied here (Yates and Halley, 2003; Albright et al. 2013; Albright et al. 2015; Koweek et al. 2015) with instances of net dissolution mainly taking place at night, coinciding with net respiration (and most likely with low gross calcification) (Cyronak et al. 2018). However, the community calcification budget over 24 hours resulting from these shifts in the present study results in a modest average accretion rate of $5.7 \mathrm{mmol}$ $\mathrm{CaCO}_{3} \mathrm{~m}^{-2}$ day $^{-1}(95 \% \mathrm{ci}=1.2 ; 3.1)$ on coral-dominated substrates. This is low compared to rates reported for reef flats worldwide (with an average around $130 \mathrm{mmol} \mathrm{CaCO}_{3} \mathrm{~m}^{-2}$ day-1 and ranging from 20 to $250 \mathrm{mmol} \mathrm{CaCO}_{3} \mathrm{~m}^{-2}$ day $^{-1}$; Atkinson, 2011). Overall, the limited number of in situ flux-based experiments carried out in the wider Caribbean (Yates and Halley 2003; Muehllehner et al. 2016; van Heuven et al. 2018) suggest they are among the lowest NCC rates recorded worldwide (Albright et al. 2015; Shaw et al. 2015; Silverman, 2007) an particularly low compared to those in the Indo-Pacific region (Koweet et al. 2015; Takeshita et al. 2016). Surveys using a census-based approach (Perry et al. 2013; de Bakker et al. 2019) also showed that some Caribbean reefs are net eroding. The recorded low rates of net carbonate production in the wider Caribbean may be expected simply due to the region-wide decrease in coral coverage since the 1970s. However, the decrease in net calcification relative to historical values is likely related to more than just coral cover loss. Indeed, the latter has subsequently left surfaces available for colonisation by turf, macroalgae (Hughes, 1994) and more recently, cyanobacterial mats (de Bakker et al. 2017). Shallow reefs around Curaçao $(<10 \mathrm{~m})$ are covered by filamentous algal turf canopies that presently represent the most dominant benthic component on these reefs (Vermeij et al. 2010). Given their abundance and high 
https://doi.org/10.5194/bg-2021-64

Preprint. Discussion started: 23 March 2021

(c) Author(s) 2021. CC BY 4.0 License.

\section{(c) (i)}

release rates of dissolved organic carbon (Mueller et al. 2016), heterotrophic activity is likely to be stimulated. Furthermore, cyanobacterial mats release part of their photosynthetically fixed carbon as DOC into the water column at a higher rate than turf and macroalgae (Mueller et al. 2014; Brocke et al. 2015). They have been shown to be responsible for 79\% of the total DOM release over a $24 \mathrm{~h}$ diel cycle at this same study site (Brocke et al. 2015). Considering their proliferation around the islands of Curaçao and Bonaire since 2003 (De Bakker et al. 2017) and the prevalence of turf algae in the area, an accumulation of organic matter may have resulted in a reduction of $\mathrm{pH}$ due to oxidation of organic matter, i.e. stimulated heterotrophic activity, resulting in reduced calcification (Bates et al. 2010). Muehllehner et al. (2016) suggested that the seasonal character of reef dissolution they recorded on the Florida Reef Tract coincided with an accumulation of organic matter, following the die-off of annual sea grasses in the area. In the present study, incubations took place in Feb-March when water temperature is lower $\left(\sim 26^{\circ} \mathrm{C}\right)$ than Aug-October $\left(\sim 29^{\circ} \mathrm{C}\right)$ for instance. Average ambient $\mathrm{pH}$ was 7.9 which did not alter significantly between day and night. This is lower than average 'summer' pH which is usually between 8.1 and 8.2 (den Haan et al. 2016) within this area indicating a potential seasonality component to reef dissolution in the Piscadera Bay.

\subsection{Net heterotrophic reef}

Low net community production rates in the current study indicate that autotrophic processes dominate modestly during the day. Integrating the NCP values over 24 hours (day + night) yielded rates skewed towards net respiration, indicating heterotrophy in all incubations. Although net community production of reef flats has been reported to vary notably over the course of the day (Koweek et al. 2015), with values ranging from -220 to $+310 \mathrm{mmol} \mathrm{m}^{-2}$ day $^{-1}$ (Atkinson, 2011), large amplitude shifts between net autotrophy and net heterotrophy are usually recorded between day and night (Yates and Halley, 2003; Albright et al. 2013; Albright et al. 2015; Koweek et al. 2015). Here, the amplitude of this shift between day and night is modest. It should be noted however, that the reduction in light intensity by $17 \%$ on average may have resulted in a slight underestimation of NCP measurements. This would hold especially true for BCM incubations. Reductions in light would intensify down the steep vertical physiochemical gradients present in these microbial mats, and could interfere with lightcontrolled circadian regulation of photosynthesis and respiration in these cooperative communities (Hörnlein et al. 2018), favouring respiration and decreasing net community productivity.

The reduction in the amplitude of the diel shift in net production and calcification recorded in the present study may have severe implications. For instance, metabolic fluctuations from reef biota cause strong temporal fluxes in compounds which affect the oscillatory behaviour of reef seawater microbial communities (Kelly et al. 2019; Weber et al. 2020) leading to less distinct populations and more redundancy in microbial specialists' functions, i.e. a shift to a dominance in catabolic pathways. Organic material supplied to the ecosystem by benthic primary producers as exudates is also thought to play a pivotal role on microbial growth (Haas et al. 2011) and diversity (Nelson et al. 2013; Haas et al. 2016) depending on its origin. Studies on the effect of exudates of macroalgae and turf on microbial metabolism demonstrated that the composition of exudates stimulated rapid growth of less diverse microbe communities compared with coral derived exudates. Microbial communities shift towards copiotrophic populations that have the potential to remineralise available organic nutrients at a high rate and encode greater 
https://doi.org/10.5194/bg-2021-64

Preprint. Discussion started: 23 March 2021

(c) Author(s) 2021. CC BY 4.0 License.

(c) (i)

numbers of potential virulence factor genes, ultimately harming corals and maintaining algal dominance (Nelson et al. 2013; Dinsdale and Rohwer, 2011). We infer that the amount and type of organic matter provided by abundant algal turfs mats on this reef, likely enhances heterotroph activity and stimulates the proliferation of less diverse copiotrophic microbial populations, rendering the studied reef net heterotrophic regardless of substrate type.

\subsection{Nitrogen cycling}

320 Nitrogen pathways support high primary productivity in oligotrophic environments by supplying nutrients while simultaneously preventing the build-up of excess nutrients that may favour opportunistic primary producers such as algal turfs (e.g. O’Neil and Capone, 2008; Karcher et al. 2020). The abundance of non-coral primary producers on these reefs suggest that nitrogen is not a limiting factor for growth. Results showed that all substrate types acted as $\mathrm{NH}_{4}{ }^{+}$and $\mathrm{NO}_{3}{ }^{-}$sources during the day and the night, with the exception of sand and turf substrates which acted as sinks for $\mathrm{NO}_{3}{ }^{-}$. This is to be expected from overall net heterotrophic communities, however, even in instances of net autotrophy during the day, substrates still acted as DIN sources. This is comparable to recent results from in situ incubations carried out in the central Red Sea on net autotrophic coral and algae-dominated communities (Roth et al. 2020). The concurrent community-wide processes such as the consumption and transformation of organic matter by microbial populations (e.g. Pfister and Altabet, 2019) are expected to mask the assimilation of DIN by primary producers.

330 Nitrification and denitrification rates measured in the present study generally fall within the published range of in situ measurements in tidal pools dominated by algae and corals (Webb and Wieber, 1975), in cavities covered in encrusting sponges (Scheffers et al. 2004), on cyanobacterial mats (Bonin and Michotey, 2006) and on carbonate sand (Capone et al. 1992; Eyre et al. 2013b). However, there was no nitrification during the day (except for the community dominated by sponges), which may be explained by light causing a reduced activity of nitrifiers (Kwon et al. 2020). Owing to the rather shallow depths of our experiment, nitrifiers may have been negatively affected by the light. As mentioned above, microbial communities are impacted by organic matter composition and temporal fluctuations in biogeochemicals. Shifts in diversity and abundance of the microbial communities inhabiting the reef substrate may also lead to diel shifts in nitrogen-cycling capacity (Rädecker et al. 2015). Further research investigating how alterations in diversity and abundance of these microbial functional groups relate to changes in the nitrogen-cycling capacity of reef assemblages is needed at this point.

\section{$340 \quad 4.4$ Functional homogenisation}

Although processes recorded on distinct community assemblages show some variation between substrate types, a multivariate pairwise analysis revealed that there is no significant difference between overall processes occurring on any of the assemblages. Expectedly, significant variation is found between day and night for all processes. Considering the differences in benthic composition, these results suggest that some degree of functional homogenisation (Clavel et al. 2011) exists between substrates

345 with distinctly different community compositions. Results indicate that even on substrates with coral cover ranging from $34 \%$ to $36 \%$, which is high relative to the Caribbean region (de Bakker et al. 2016 and 2019), net community calcification is very 
https://doi.org/10.5194/bg-2021-64

Preprint. Discussion started: 23 March 2021

(c) Author(s) 2021. CC BY 4.0 License.

(c) (i)

low. In fact, daily rates are in a similar range to those for substrates dominated by bioeroding sponges where coral cover ranged from 1 to $9 \%$ and to substrates covered by cyanobacterial mats where no live coral was recorded. This suggests that cementation/lithification processes carried out by coralline calcifying algae, micro-calcifiers (e.g. foraminifera and juvenile shells) and benthic microbial communities, resulting in the trapping and binding of rubble and sediment in cryptic habitats and within/on the rubble, may play an important role on such impacted coral reefs, counteracting some of the dissolution in these communities and stabilising coral rubble into a consolidated reef framework.

The main differences between coral-dominated substrates and others, in terms of NCC, is that they can balance out dissolution at night, whereas other communities cannot. Primary production is barely compensating heterotrophic processes during the day on all substrates. Although substrates incubated in the present study are distinct in taxa dominance, they do share some similarities that may be drawing biological function differences closer to each other between distinct benthic assemblages. Indeed, turf covers any part of hard substrate available, the sand and rubble harbour a variety of potentially similar cryptic organisms and the microbial community within and above each of these substrates may be shifting similarly towards generalist copiotrophic populations. These shifts in community composition have resulted in the impairment of key reef functions that are usually attributed to conventional reefs, leading to functional homogenisation among these communities. It is noteworthy that this functional homogenisation on degraded reefs might be the result of seasonality. Roth et al. (2020) recently found that summer temperatures amplified functional differences between coral- and algae-dominated communities in the central Red Sea. Higher temperatures benefit algae-dominated communities in terms of primary production and growth while coraldominated communities shifted towards a more heterotrophic state with depressed net community calcification rates. The fact

365 that coral-dominated substrates studied here are already in a heterotrophic state with very low NCC values in winter temperatures attests to the differences in the studied systems and provides an opportunity for comparison between a relatively healthy system and a degraded one (Roff and Mumby, 2012). However, further research looking at the seasonal component of the functionality of these degraded systems is essential to understand how they will respond to higher temperatures.

\section{Conclusions}

370 The combination of in situ incubations and inverse modelling taking into account the complexity of interactions between processes, has proven to be an effective tool to provide quantitative data on the functional state of coral reef patches. Results acquired on this shallow Curaçaoan reef provide insight into the impact of habitat degradation and species composition shifts on reef functions. Remaining corals, although resilient, calcify at a slower pace than more specialist species (Acropora spp.) and cannot balance out heterotrophic processes from other functional groups. Coral presence does however contribute to counteracting dissolution processes at night, therefore acting as buffers to reef deconstruction. In the context of ongoing global change, the environmental resilience of generalist species could be a determining factor of ecosystem stability (Clavel et al. 2011). For instance, on some reef terrace of the fringing reefs of Curaçao and Bonaire (southern Caribbean), some stretches appear to harbour a considerable cover of steadily growing little boulder-constructing tolerant corals (including mainly 
https://doi.org/10.5194/bg-2021-64

Preprint. Discussion started: 23 March 2021

(c) Author(s) 2021. CC BY 4.0 License.

(c) (i)

(Pseudo)Diploria spp., Porites astreoides and Siderastrea sidereal) (de Bakker et al. 2019). Surprisingly, these are often found

near areas which have locally suffered chronic stress from terrestrial sources (i.e. inflow, intense coastal development, factory outflow) but often limited to areas covered by hard substrate and relatively less sand. Data on the processes underlying such developments however is virtually absent, but this could indicate that even the most severely degraded reefs could slowly regain essential functions when a critical adaptive capacity is reached.

Data and code availability Data and $\mathrm{R}$ code will be made available on request.

Author's contributions AW, DdB, SvH and LdN conceived the ideas and designed methodology; AW, DdB and TdC collected the data; AW and KS analysed the data; AW and LdN led the writing of the manuscript in consultation with DdB, SvH, FvD, KS and GR. All authors contributed critically to the drafts and gave final approval for publication.

Competing Interests The authors declare that they have no conflict of interest.

Acknowledgements The authors are particularly grateful to the Carmabi research station as a whole and especially Mark Vermeij for his support and facilitating the fieldwork on Curaçao. We would also like to thank Jasper de Goeij for lending us equipment. We extent our sincere gratitude to Karel Baker and Sharyn Ossebaar for analysing nutrient and DIC samples.

\section{References}

Atkinson, M. J.: Biogeochemistry of nutrients. In Coral reefs: An ecosystem in transition, 199-206, Springer, Dordrecht, 2011. Albright, R., Langdon, C., and Anthony, K. R. N.: Dynamics of seawater carbonate chemistry, production, and calcification of a coral reef flat, central Great Barrier Reef, Biogeosciences Discuss., 10(5), 7641-7676, 2013.

400 Albright, R., Benthuysen, J., Cantin, N., Caldeira, K. and Anthony, K.: Coral reef metabolism and carbon chemistry dynamics of a coral reef flat, Geophys. Res. Lett, 42(10), 3980-3988, doi: 10.1002/2015GL063488, 2015.

Alvarez-Filip, L., Dulvy, N. K., Gill, J. A., Côté, I. M. and Watkinson, A. R.: Flattening of Caribbean coral reefs: Region-wide declines in architectural complexity, Proc. Royal Soc. B., 276(1669), 3019-3025, doi: 10.1098/rspb.2009.0339, 2009.

Andersson, A. J. and Gledhill, D.: Ocean Acidification and Coral Reefs: Effects on breakdown, dissolution, and net ecosystem

405 calcification, Ann Rev Mar Sci, 5(1), 321-348, doi: 10.1146/annurev-marine-121211-172241, 2013.

Aronson, R. B., Macintyre, I. G., Lewis, S. A., and Hilbun, N. L.: Emergent zonation and geographic convergence of coral reefs, Ecology, 86(10), 2586-2600, 2005.

Bates, N. R., Amat, A. and Andersson, A. J.: Feedbacks and responses of coral calcification on the Bermuda reef system to seasonal changes in biological processes and ocean acidification, Biogeosciences, 2, 2509-2530, doi: 10.5194/bg-7-2509-

$410 \quad 2010,2010$. 
https://doi.org/10.5194/bg-2021-64

Preprint. Discussion started: 23 March 2021

(c) Author(s) 2021. CC BY 4.0 License.

\section{(c) (1)}

Barott, K. L., Williams, G. J., Vermeij, M. J., Harris, J., Smith, J. E., Rohwer, F. L., and Sandin, S. A.: Natural history of coral- algae competition across a gradient of human activity in the Line Islands, Mar. Ecol. Prog. Ser., 460, 1-12, 2012.

Bonin, P. C., and Michotey, V. D.: Nitrogen budget in a microbial mat in the Camargue (southern France), Mar. Ecol. Prog. Ser., 322, 75-84, 2006.

415 Brandl, S. J., Rasher, D. B., Côté, I. M., Casey, J. M., Darling, E. S., Lefcheck, J. S., and Duffy, J. E.: Coral reef ecosystem functioning: eight core processes and the role of biodiversity, Front. Ecol. Environ., 17(8), 445-454, 2019.

Brocke, H. J., Wenzhoefer, F., de Beer, D., Mueller, B., van Duyl, F. C. and Nugues, M. M.: High dissolved organic carbon release by benthic cyanobacterial mats in a Caribbean reef ecosystem, Sci. Rep., 5(1), 8852, doi: 10.1038/srep08852, 2015. Brocke, H.J., Piltz, B., Herz, N., Abed, R.M., Palinska, K.A., John, U., den Haan, J., de Beer, D. and Nugues, M.M.: Nitrogen fixation and diversity of benthic cyanobacterial mats on coral reefs in Curaçao, Coral Reefs, 37(3), 861-874, 2018.

Burman, S. G., Aronson, R. B., \& van Woesik, R.: Biotic homogenization of coral assemblages along the Florida reef tract, Mar. Ecol. Prog. Ser., 467, 89-96, 2012.

Capone, D. G., Dunham, S. E., Horrigan, S. G., and Duguay, L. E.: Microbial nitrogen transformations in unconsolidated coral reef sediments, Mar. Ecol. Prog. Ser., 75-88, 1992.

425 Chen, P. Y., Chen, C. C., Chu, L. F. and McCarl, B.: Evaluating the economic damage of climate change on global coral reefs, Glob. Environ. Change, 30, 12-20. doi: 10.1016/j.gloenvcha.2014.10.011, 2015.

Clavel, J., Julliard, R., and Devictor, V.: Worldwide decline of specialist species: toward a global functional homogenization?, Front. Ecol. Environ., 9(4), 222-228, 2011.

Clements, K. D., German, D. P., Piché, J., Tribollet, A., \& Choat, J. H.: Integrating ecological roles and trophic diversification on coral reefs: multiple lines of evidence identify parrotfishes as microphages, Biol. J. Linn. Soc., 120(4), 729-751, 2016.

Courtney, T.A., Andersson, A.J., Bates, N.R., Collins, A., Cyronak, T., de Putron, S.J., Eyre, B.D., Garley, R., Hochberg, E.J., Johnson, R. and Musielewicz, S.: Comparing chemistry and census-based estimates of net ecosystem calcification on a rim reef in Bermuda, Front. Mar. Sci., 3, 181, 2016.

Cramer, K., Donovan, M., Jackson, J., Greenstein, B., Korpanty, C., Cook, G., and Pandolfi, J.: The transformation of 435 Caribbean coral communities since humans, Authorea Preprints, 2021.

Cyronak, T., Andersson, A. J., Langdon, C., Albright, R., Bates, R., Caldeira, K., Carlton, R., Corredor, J. E., Dunbar, R. B., Enochs, I., Erez, J., Eyre, B. D., Gattuso, J., Lantz, C., Lazar, B., Manzello, D., Mcmahon, A., Mele, M., Page, H. N., Santos, I. R., Schulz, K. G., Shaw, E. and Silverman, J.: Taking the metabolic pulse of the world's coral reefs, PloS one, 1-17, 2018. Darling, E. S., Alvarez-Filip, L., Oliver, T. A., McClanahan, T. R., and Côté, I. M.: Evaluating life-history strategies of reef 440 corals from species traits, Ecol. Lett., 15(12), 1378-1386, 2012.

De'ath, G., Fabricius, K. E., Sweatman, H. and Puotinen, M.: The 27 - year decline of coral cover on the Great Barrier Reef and its causes, Proc. Natl. Acad. Sci. U. S. A., doi: 10.1073/pnas.1208909109, 2012. 
https://doi.org/10.5194/bg-2021-64

Preprint. Discussion started: 23 March 2021

(c) Author(s) 2021. CC BY 4.0 License.

(c) (i)

de Bakker, D. M., van Duyl, F. C., Perry, C. T., and Meesters, E. H.: Extreme spatial heterogeneity in carbonate accretion potential on a Caribbean fringing reef linked to local human disturbance gradients, Glob. Change Biol., 25(12), 4092-4104, 2019.

de Bakker, D. M., Webb, A. E., van den Bogaart, L. A., van Heuven, S. M., Meesters, E. H., and van Duyl, F. C.: Quantification of chemical and mechanical bioerosion rates of six Caribbean excavating sponge species found on the coral reefs of Curaçao, PloS one, 13(5), e0197824, 2018.

de Bakker, D. M., van Duyl, F. C., Bak, R. P. M., Nugues, M. M., Nieuwland, G. and Meesters, E. H.: 40 Years of benthic community change on the Caribbean reefs of Curaçao and Bonaire: the rise of slimy cyanobacterial mats, Coral Reefs, Springer Berlin Heidelberg, 36(2), 355-367, doi: 10.1007/s00338-016-1534-9, 2017.

de Bakker, D. M., Meesters, E. H., Bak, R. P. M., Nieuwland, G. and Van Duyl, F. C.: Long-term Shifts in Coral Communities On Shallow to Deep Reef Slopes of Curaçao and Bonaire: Are There Any Winners?, Front. Mar. Sci., 1-14, doi: 10.3389/fmars.2016.00247, 2016.

den Haan, J., Huisman, J., Brocke, H.J., Goehlich, H., Latijnhouwers, K.R., Van Heeringen, S., Honcoop, S.A., Bleyenberg, T.E., Schouten, S., Cerli, C. and Hoitinga, L.: Nitrogen and phosphorus uptake rates of different species from a coral reef community after a nutrient pulse, Sci. Rep., 6(1), 1-13, 2016.

Dickson, A. G., Sabine, C. L., and Christian, J. R.: Guide to best practices for ocean CO2 measurements, North Pacific Marine Science Organization, 2007.

Dinsdale, E. A., and Rohwer, F.: Fish or germs? Microbial dynamics associated with changing trophic structures on coral reefs. In Coral reefs: an ecosystem in transition, 231-240, Springer, Dordrecht, 2011.

Eyre, B. D., Santos, I. R., and Maher, D. T.: Seasonal, daily and diel N2 effluxes in permeable carbonate sediments, Biogeosciences, 10(4), 2601-2615, 2013.

Gardner, T. A., Côté, I. M., Gill, J. A., Grant, A. and Watkinson, A. R.: Long-term Regional-wide declining in Caribbean corals, Science, 301(5635), 958-960, doi: 10.1126/science.1086050, 2003.

Haas, A.F., Nelson, C.E., Kelly, L.W., Carlson, C.A., Rohwer, F., Leichter, J.J., Wyatt, A. and Smith, J.E.: Effects of coral reef benthic primary producers on dissolved organic carbon and microbial activity, PloS one, 6(11), e27973, 2011.

Haas, A. F., Nelson, C. E., Rohwer, F., Wegley-Kelly, L., Quistad, S. D., Carlson, C. A., Leichter, J. J., Hatay, M. and Smith, J. E.: Influence of coral and algal exudates on microbially mediated reef metabolism, PeerJ, 1, e108,doi: 10.7717/peerj.108, 4702013.

Haas, A.F., Fairoz, M.F., Kelly, L.W., Nelson, C.E., Dinsdale, E.A., Edwards, R.A., Giles, S., Hatay, M., Hisakawa, N., Knowles, B. and Lim, Y.W.: Global microbialization of coral reefs, Nat. Microbiol, 1(6), 1-7, 2016.

Holm, S.: A simple sequentially rejective multiple test procedure, Scand. J. Stat., 65-70, 1979.

Hörnlein, C., Confurius-Guns, V., Stal, L. J., and Bolhuis, H.: Daily rhythmicity in coastal microbial mats, NPJ Biofilms

Microbiomes, 4(1), 1-11, 2018. 
https://doi.org/10.5194/bg-2021-64

Preprint. Discussion started: 23 March 2021

(c) Author(s) 2021. CC BY 4.0 License.

(c) (i)

Hughes, T. P.: Catastrophes, phase shifts, and large-scale degradation of a Caribbean coral reef, Science, 265(5178), 1547$1551,1994$.

Hughes, T.P., Barnes, M.L., Bellwood, D.R., Cinner, J.E., Cumming, G.S., Jackson, J.B., Kleypas, J., Van De Leemput, I.A., Lough, J.M., Morrison, T.H. and Palumbi, S.R., Coral reefs in the Anthropocene, Nature, 546(7656), 82-90, 2017.

Hydes, D. J., Aoyama, M., Aminot, A., Bakker, K., Becker, S., Coverly, S., Daniel, A., Dickson, A. G., Grosso, O., Kerouel, R., Van Ooijen, J., Sato, K., Tanhua, T., Woodward, M. and Zhang, J. Z.: Determination of dissolved nutrients (N, P, Si) in seawater with high precision and inter-comparability using gas-segmented continuous flow analysers, The GO-SHIP Repeart Hydrography Manual: A Collection of Expert Reports and Guidelines, 1-87, available at: http://archimer.ifremer.fr/doc/00020/13141/, 2010.

485 Jackson, J. B. C., Donovan, M. K., Cramer, K. L. and Lam, V.: Status and Trends of Caribbean Coral Reefs : 1970-2012, GCRMN, IUCN, Gland, Switzerland, 306, doi: 10.1242/jeb.061267, 2014.

Karcher, D.B., Roth, F., Carvalho, S., El-Khaled, Y.C., Tilstra, A., Kürten, B., Struck, U., Jones, B.H. and Wild, C.: Nitrogen eutrophication particularly promotes turf algae in coral reefs of the central Red Sea, PeerJ, 8, e8737, 2020.

Kelly, L.W., Nelson, C.E., Haas, A.F., Naliboff, D.S., Calhoun, S., Carlson, C.A., Edwards, R.A., Fox, M.D., Hatay, M., Johnson, M.D. and Kelly, E.L.: Diel population and functional synchrony of microbial communities on coral reefs, Nat. Commun, 10(1), 1-9, 2019.

Kline, D.I., Teneva, L., Schneider, K., Miard, T., Chai, A., Marker, M., Headley, K., Opdyke, B., Nash, M., Valetich, M. and Caves, J.K.: A short-term in situ CO2 enrichment experiment on Heron Island (GBR), Sci. Rep., 2(1), 1-9, 2012.

Koop, K., Booth, D., Broadbent, A., Brodie, J., Bucher, D., Capone, D., Coll, J., Dennison, W., Erdmann, M., Harrison, P., 495 Hoegh-Guldberg, O., Hutchings, P., Jones, G. B., Larkum, A. W. D., O’Neil, J., Steven, A., Tentori, E., Ward, S., Williamson, J. and Yellowlees, D.: ENCORE: The effect of nutrient enrichment on coral reefs. Synthesis of results and conclusions, Mar. Pollut. Bull, 42(2), 91-120, doi: 10.1016/S0025-326X(00)00181-8, 2001.

Kwon, G., Le, L. T., Jeon, J., Noh, J., Jang, Y., Kang, D., and Jahng, D.: Effects of light and mass ratio of microalgae and nitrifiers on the rates of ammonia oxidation and nitrate production, Biochem. Eng. J., 107656, 2020.

500 Koweek, D., Dunbar, R. B., Price, N., Mucciarone, D. and Teneva, L.: Environmental and ecological controls of coral community metabolism on Palmyra Atoll, Coral Reefs, 339-351, doi: 10.1007/s00338-014-1217-3, 2015.

Langdon, C. and Atkinson, M. J.: Effect of elevated pCO2 on photosynthesis and calcification of corals and interactions with seasonal change in temperature/ irradiance and nutrient enrichment, J. Geophys. Res. Oceans, 110(9), 1-16, doi: 10.1029/2004JC002576, 2005.

505 Lavigne, H., Proye, A., and Gattuso, J. P.: Package seacarb, Laboratoire d'Océanographie de Villefranche (LOV) France, 2009.

Liu, X., Byrne, R. H., Lindemuth, M., Easley, R. and Mathis, J. T.: An automated procedure for laboratory and shipboard spectrophotometric measurements of seawater alkalinity: Continuously monitored single-step acid additions, Mar. Chem., 174, 141-146, doi: 10.1016/j.marchem.2015.06.008, 2015. 
https://doi.org/10.5194/bg-2021-64

Preprint. Discussion started: 23 March 2021

(c) Author(s) 2021. CC BY 4.0 License.

(c) (i)

Matsuzaki, S. I. S., Sasaki, T., \& Akasaka, M.: Consequences of the introduction of exotic and translocated species and future extirpations on the functional diversity of freshwater fish assemblages, Glob. Ecol. Biogeogr., 22(9), 1071-1082, 2013.

McGill, B. J., Dornelas, M., Gotelli, N. J., \& Magurran, A. E.: Fifteen forms of biodiversity trend in the Anthropocene, Trends Ecol. Evol., 30(2), 104-113, 2015.

McWilliam, M., Hoogenboom, M. O., Baird, A. H., Kuo, C. Y., Madin, J. S., \& Hughes, T. P.: Biogeographical disparity in the functional diversity and redundancy of corals, Proc. Natl. Acad. Sci. U. S. A., 115(12), 3084-3089, 2018.

Moberg, F., and Folke, C.: Ecological goods and services of coral reef ecosystems, Ecol Econ, 29(2), 215-233, 1999.

Muehllehner, N., Langdon, C., Venti, A. and Kadko, D.: Dynamics of carbonate chemistry, production, and calcification of the Florida Reef Tract (2009-2010): Evidence for seasonal dissolution, Global Biogeochem Cycles, 661-688, doi: 10.1002/2015GB005327, 2016.

520 Mueller, B., Goeij, J. M. De, Vermeij, M. J. A., Mulders, Y., Ent, E. Van Der, Ribes, M. and van Duyl, F. C.: Natural Diet of Coral-Excavating Sponges Consists Mainly of Dissolved Organic Carbon (DOC), PloS one, 9(2), doi: 10.1371/journal.pone.0090152, 2014.

Mueller, B., Den Haan, J., Visser, P. M., Vermeij, M. J., and Van Duyl, F. C.: Effect of light and nutrient availability on the release of dissolved organic carbon (DOC) by Caribbean turf algae, Sci. Rep., 6(1), 1-9, 2016.

525 Nelson, C. E., Goldberg, S. J., Kelly, L. W., Haas, A. F., Smith, J. E., Rohwer, F., and Carlson, C. A.: Coral and macroalgal exudates vary in neutral sugar composition and differentially enrich reef bacterioplankton lineages, ISME J, 7(5), 962-979, 2013.

Oksanen, J., Kindt, R., Legendre, P., O’Hara, B., Stevens, M. H. H., Oksanen, M. J., and Suggests, M. A. S. S.: The vegan package, Community ecology package, 10(631-637), 719, 2007.

530 Oliver, T.H., Heard, M.S., Isaac, N.J., Roy, D.B., Procter, D., Eigenbrod, F., Freckleton, R., Hector, A., Orme, C.D.L., Petchey, O.L. and Proença, V.: Biodiversity and resilience of ecosystem functions, Trends Ecol. Evol., 30(11), pp.673-684, 2015.

O’Neil, J. M., and Capone, D. G.: Nitrogen cycling in coral reef environments, Nitrogen in the marine environment, Eds.: Capone, D.G., Bronk, D.A., Mulholland, M.R., and Carpenter, E.J., 949-989, 2008.

Perry, C. T., Murphy, G. N., Kench, P. S., Smithers, S. G., Edinger, E. N., Steneck, R. S., and Mumby, P. J.: Caribbean-wide 535 decline in carbonate production threatens coral reef growth, Nat. Commun, 4, 1402, 2013.

Petsch, D.K., Saito, V.S., Landeiro, V.L., Silva, T.S., Bini, L.M., Heino, J., Soininen, J., Tolonen, K.T., Jyrkänkallio-Mikkola, J., Pajunen, V. and Siqueira, T.: Beta diversity of stream insects differs between boreal and subtropical regions, but land use does not generally cause biotic homogenization, Freshw. Sci., 40(1), 000-000, 2020.

Pfister, C. A., and Altabet, M. A.: Enhanced microbial nitrogen transformations in association with macrobiota from the rocky 540 intertidal, Biogeosciences, 16(2), 193-206, 2019.

Rädecker, N., Pogoreutz, C., Voolstra, C. R., Wiedenmann, J., and Wild, C.: Nitrogen cycling in corals: the key to understanding holobiont functioning?, Trends Microbiol., 23(8), 490-497, 2015. 
https://doi.org/10.5194/bg-2021-64

Preprint. Discussion started: 23 March 2021

(c) Author(s) 2021. CC BY 4.0 License.

(c) (i)

Roff, G. and Mumby, P. J.: Global disparity in the resilience of coral reefs, Trends Ecol. Evol., Elsevier Ltd, 27(7), 404-413, doi: 10.1016/j.tree.2012.04.007, 2012.

545 Roth, F., Rädecker, N., Carvalho, S., Duarte, C.M., Saderne, V., Anton, A., Silva, L., Calleja, M.L., Morán, X.A.G., Voolstra, C.R. and Kürten, B.: High summer temperatures amplify functional differences between coral-and algae-dominated reef communities, Ecology, p.e03226, 2020.

Scheffers, S. R., Nieuwland, G., Bak, R. P. M., and Van Duyl, F. C.: Removal of bacteria and nutrient dynamics within the coral reef framework of Curaçao (Netherlands Antilles), Coral Reefs, 23(3), 413-422, 2004.

Shaw, E. C., Phinn, S. R., Tilbrook, B. and Steven, A.: Natural in situ relationships suggest coral reef calcium carbonate production will decline with ocean acidification. Limnol. Oceanogr., 60(3), 777-788. doi: 10.1002/1no.10048, 2015.

Silverman, J., Lazar, B. and Erez, J.: Effect of aragonite saturation, temperature, and nutrients on the community calcification rate of a coral reef, J. Geophys. Res. Oceans, 112(5), 1-14, doi: 10.1029/2006JC003770, 2007.

Soetaert, K., Hofmann, A. F., Middelburg, J. J., Meysman, F. J., and Greenwood, J.: The effect of biogeochemical processes on pH, Mar. Chem., 106(1-2), 380-401, 2007.

Soetaert, K. E., Petzoldt, T., and Setzer, R. W.: Solving differential equations in R: package deSolve, J. Stat. Softw, 33, 2010. Soetaert, K., and Petzoldt, T.: Inverse modelling, sensitivity and Monte Carlo analysis in R using package FME, J. Stat. Softw, 33(3), 1-28, 2010.

Sonnier, G., Johnson, S. E., Amatangelo, K. L., Rogers, D. A., \& Waller, D. M.: Is taxonomic homogenization linked to functional homogenization in temperate forests?, Glob. Ecol. Biogeogr., 23(8), 894-902, 2014.

Takeshita, Y., McGillis, W., Briggs, E.M., Carter, A.L., Donham, E.M., Martz, T.R., Price, N.N. and Smith, J.E.: Assessment of net community production and calcification of a coral reef using a boundary layer approach, J. Geophys. Res. Oceans, 121(8), 5655-5671, 2016.

Tobias, N., \& Monika, W.: Does taxonomic homogenization imply functional homogenization in temperate forest herb layer communities?, Plant Ecol., 213(3), 431-443, 2012.

van Duyl, F. C.: Atlas of the living reefs of Curaçao and Bonaire (Netherlands Antilles), Utrecht, Netherlands Foundation for Scientific Research in Surinam and the Netherlands Antilles, 117, 1985.

van Heuven, S. M. A. C., Webb, A. E., Bakker, D. M. De, Meesters, E., Duyl, F. C. Van, Reichart, G. and Lennart, J.: In-situ incubation of a coral patch for community-scale assessment of metabolic and chemical processes on a reef slope, PeerJ, 1-24, doi: 10.7717/peerj.5966, 2018.

Vermeij, M. J., Van Moorselaar, I., Engelhard, S., Hörnlein, C., Vonk, S. M., and Visser, P. M.: The effects of nutrient enrichment and herbivore abundance on the ability of turf algae to overgrow coral in the Caribbean, PloS one, 5(12), e14312, 2010.

Webb, K. L., and Wiebe, W. J.: Nitrification on a coral reef, Can. J. Microbiol., 21(9), 1427-1431, 1975.

575 Webb, A. E., van Heuven, S. M., de Bakker, D. M., van Duyl, F. C., Reichart, G. J., and de Nooijer, L. J.: Combined effects of experimental acidification and eutrophication on reef sponge bioerosion rates, Front. Mar. Sci., 4, 311, 2017. 
https://doi.org/10.5194/bg-2021-64

Preprint. Discussion started: 23 March 2021

(c) Author(s) 2021. CC BY 4.0 License.

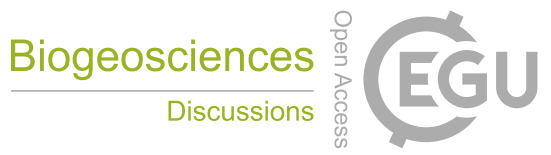

Weber, L., and Apprill, A.: Diel, daily, and spatial variation of coral reef seawater microbial communities, PloS one, 15(3), e0229442, 2020.

White, H. J., Montgomery, W. I., Storchová, L., Hořák, D., and Lennon, J. J.: Does functional homogenization accompany

taxonomic homogenization of British birds and how do biotic factors and climate affect these processes?, Ecol. Evol., 8(15), 7365-7377, 2018.

Yates, K. K. and Halley, R. B.: Measuring coral reef community metabolism using new benthic chamber technology, Coral Reefs, 22(3), 247-255, doi: 10.1007/s00338-003-0314-5, 2003.
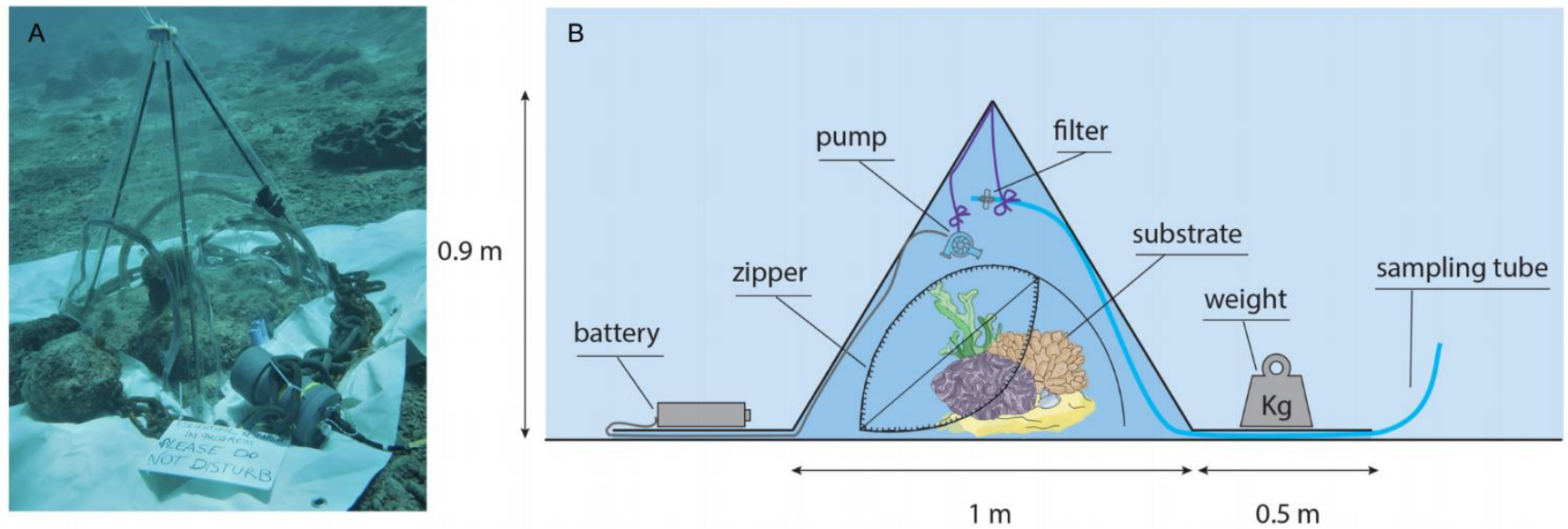

Figure 1: The tent incubation setup used. (a) Photograph depicting the tent incubation during the experiments. (b) Schematic cross section of the employed setup for enclosing a small patch of reef. A battery powered mixing propeller for maintaining water circulation, and analysers for salinity $(\mathrm{S})$, temperature $(\mathrm{T})$, oxygen $\left(\mathrm{O}_{2}\right)$, and light $(\mathrm{PAR})$ are located inside the tent. Outside the enclosure another S/T and PAR analyser were placed, as well as the battery for the pump. Sampling of exterior and interior water (though sampling tube) was performed by divers using large volume syringes. Zippers allow for opening of tent windows for reequilibrating the interior to the exterior conditions between incubations. 
https://doi.org/10.5194/bg-2021-64

Preprint. Discussion started: 23 March 2021

(c) Author(s) 2021. CC BY 4.0 License.

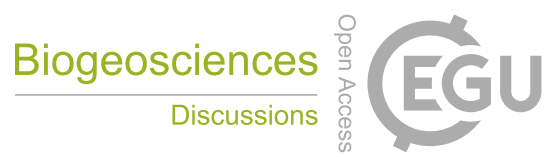

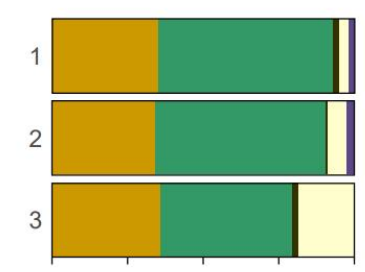
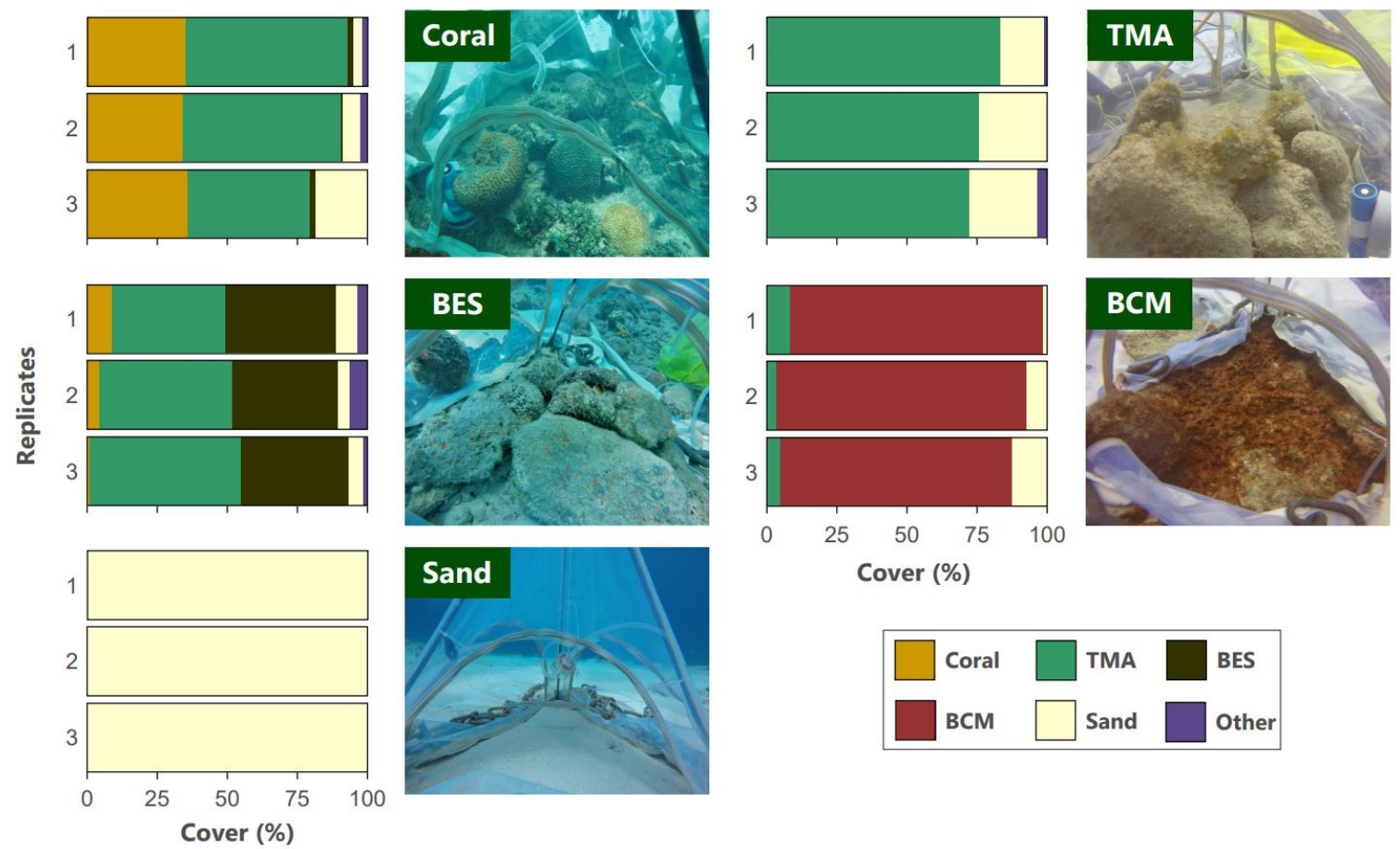

Figure 2: Benthic cover of the incubated reef communities dominated either by coral, turf and macroalgae (TMA), bioeroding sponges (BES), cyanobacterial mats (BCM) or sand with exemplary photograph. 
https://doi.org/10.5194/bg-2021-64

Preprint. Discussion started: 23 March 2021

(c) Author(s) 2021. CC BY 4.0 License.
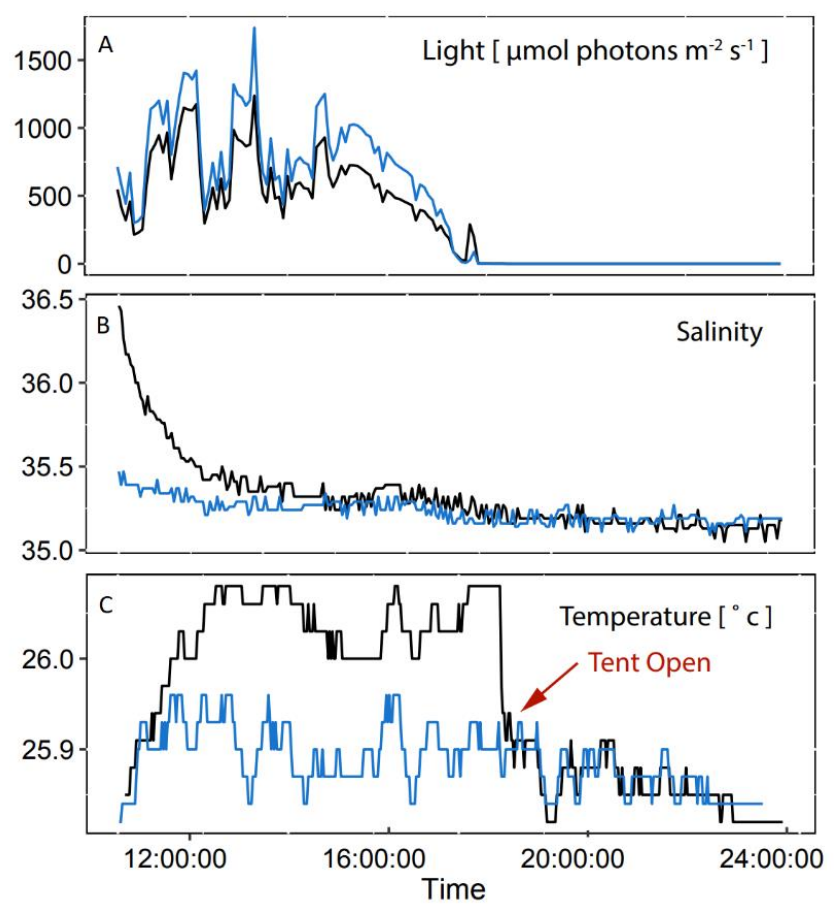

$$
\begin{aligned}
& \text {-in } \\
& \text { - out }
\end{aligned}
$$

Figure 3: Exterior and interior measurements for three representative incubations performed throughout this study. (a) Difference in light between the inside of the tent and the ambient environment during an incubation. (b) Injection of salt within the tent at the start of the incubation and its gradual return to ambient salinity. (c) Temperature within the tent compared to exterior conditions, when the tent is opened at the end of the incubation, temperature immediately returns to ambient conditions.
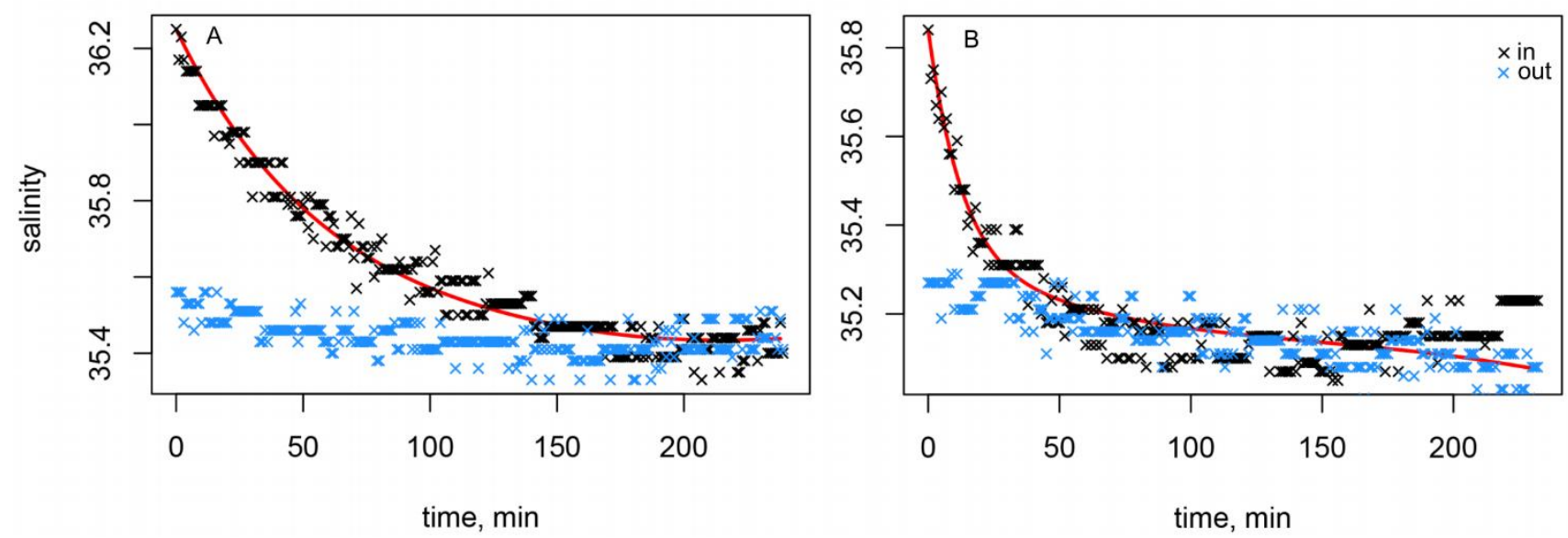

Figure 4: (a, b) Best fit explaining in-tent salinity at any given time (equation 1, red line). In-tent salinity measurements are in black and ambient salinity measurements are in blue. (a) illustrates an incubation that leaked relatively slowly with $K=0.0192(0.0192 *$ $108=2.1$ litres per minute), while (b) depicts a more rapidly leaking tent with $K=0.044(0.044 \times 108=4.8$ litres per minute). 

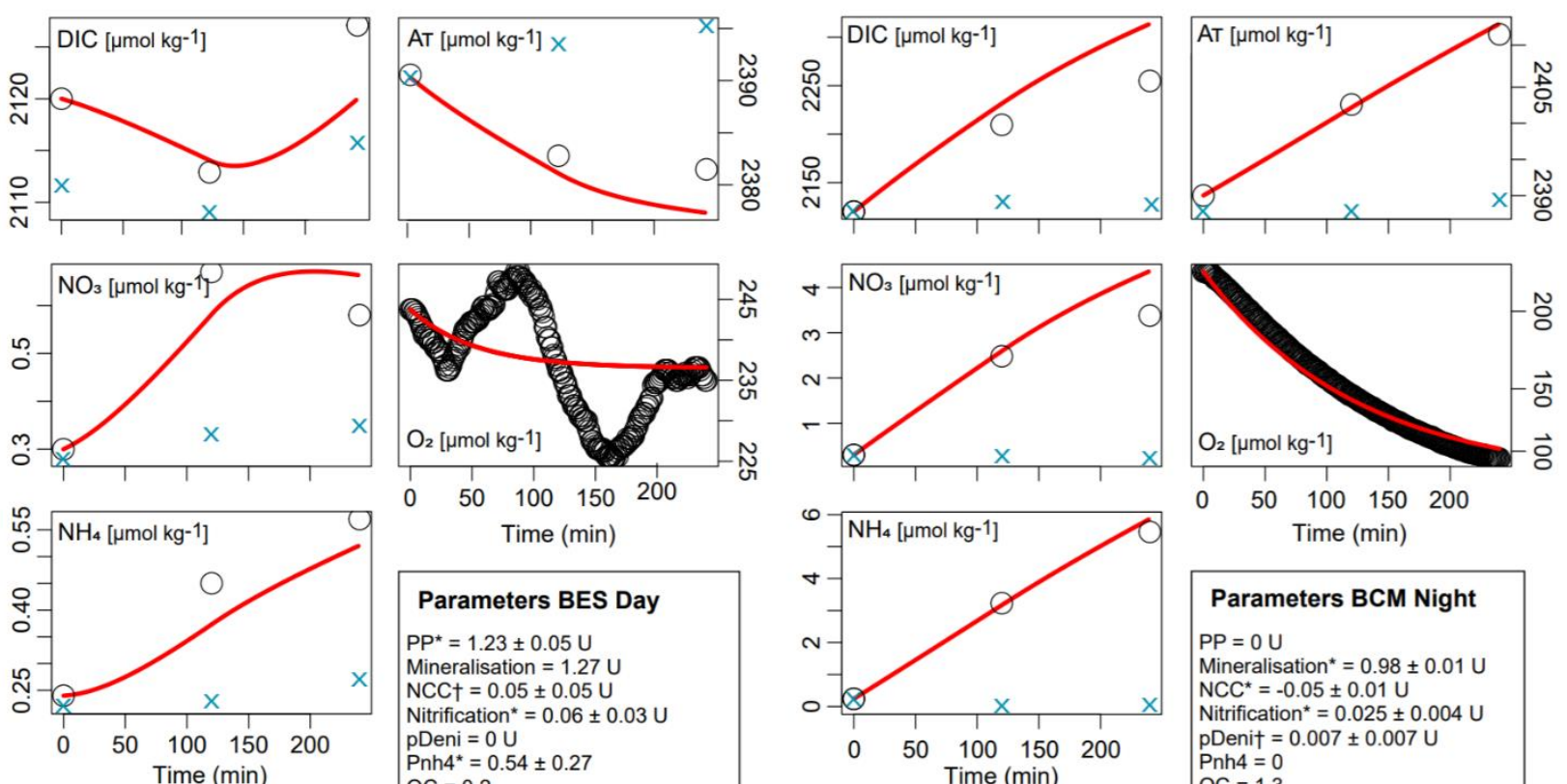

\section{Parameters BES Day}

$\mathrm{PP}^{*}=1.23 \pm 0.05 \mathrm{U}$

Mineralisation $=1.27 \mathrm{U}$

$\mathrm{NCC}+=0.05 \pm 0.05 \mathrm{U}$

Nitrification ${ }^{*}=0.06 \pm 0.03 \mathrm{U}$

pDeni $=0 \mathrm{U}$

Pnh4 $4^{*}=0.54 \pm 0.27$

$\mathrm{OC}=0.2$

NCratio $=0.1$

$\times$ ambient (measured)

interior (measured)

$\mathrm{K}=0.019$
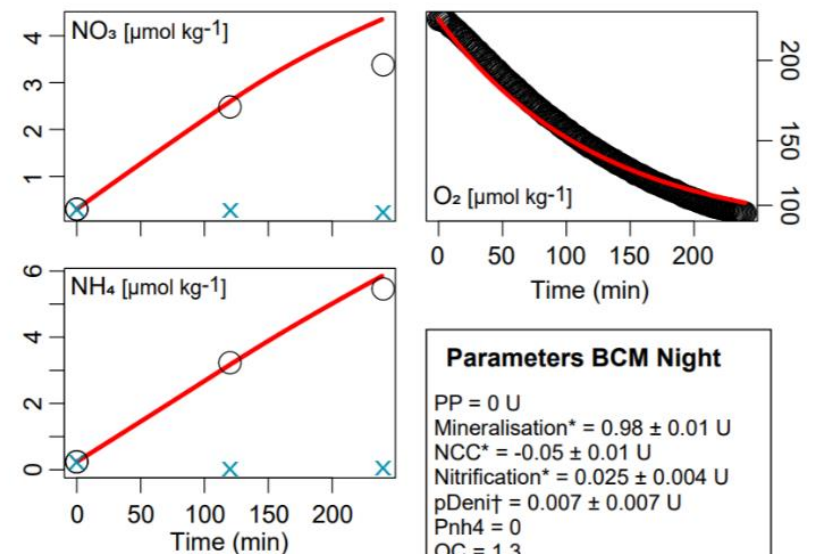

Parameters BCM Night

$\mathrm{PP}=0 \mathrm{U}$

Mineralisation $^{\star}=0.98 \pm 0.01 \mathrm{U}$

$\mathrm{NCC}^{\star}=-0.05 \pm 0.01 \mathrm{U}$

Nitrification $^{*}=0.025 \pm 0.004 \mathrm{U}$

pDeni $\dagger=0.007 \pm 0.007 \mathrm{U}$

$\mathrm{Pnh} 4=0$

$\mathrm{OC}=1.3$

NCratio $=0.05$

$\mathrm{U}=\mu \mathrm{mol} \mathrm{kg}^{-1} \min ^{-1}$

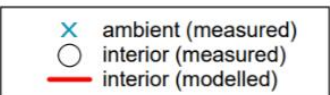

$\mathrm{K}=0.008$

$\mathrm{U}=\mu \mathrm{mol} \mathrm{kg}{ }^{-1} \min ^{-1}$

Figure 5: Illustrative results of the model (red line) employed to infer the process rates from measured data. The left panel depicts

the model output of an incubation performed during the day over a substrate dominated by bioeroding sponges (BES, Fig. 2 , replicate 1) while the right panel shows the output for a night-time incubation over a cyanobacterial mat (BCM, Fig. 2, replicate 2). Circles and crosses represent measured values of the state variables inside and outside the tent respectively. Fixed and fitted parameters used to run models are presented in bottom right boxes. Parameters escorted by the star sign * relate to significant parameter estimation (with standard error). The $\uparrow$ symbol refers to non-significant parameter estimation. The remaining parameters are fixed. Note that the fixed mineralisation parameter in the left panel was estimated from the data of the same incubation at night (we assume similar mineralisation during the day). 


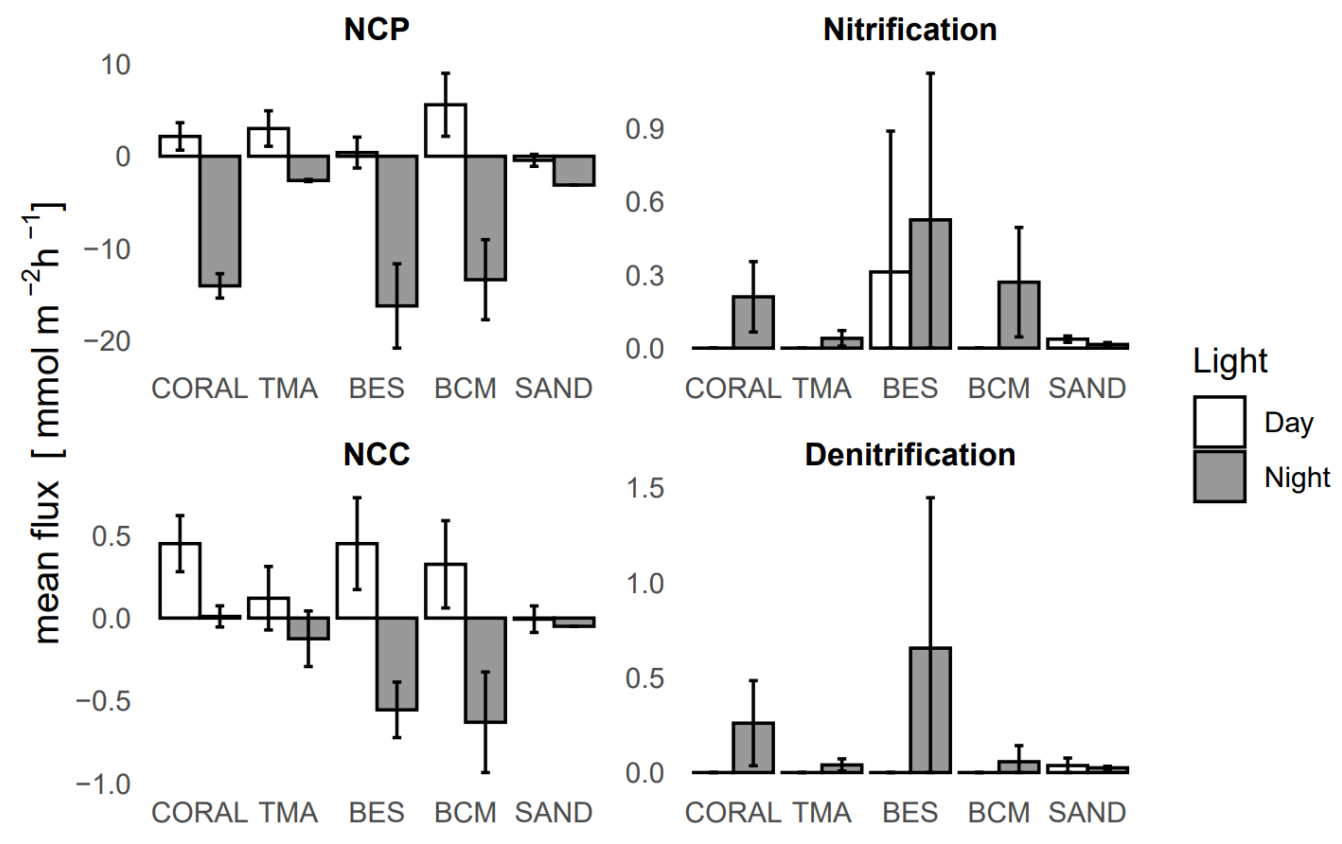

Figure 6: Average process rates with respective $95 \%$ confidence interval inferred from observed concentration changes and model output in the tent enclosure on every substrate and during all incubation periods.

Table 1: Average net community production, net community calcification, nitrification, and denitrification fluxes in benthic communities with respective $95 \%$ confidence interval inferred from observed concentration changes in the tent enclosure on every substrate and during all incubation periods. White cells show day fluxes, while grey cells depict night fluxes. Crosses relate to instances where no nitrification or denitrification was estimated by the model and the parameter was therefore fixed at 0 .

\begin{tabular}{|c|c|c|c|c|c|c|c|c|c|c|c|c|}
\hline \multirow{4}{*}{$\begin{array}{c}\begin{array}{c}\text { Substrate } \\
\text { Type }\end{array} \\
\text { CORAL }\end{array}$} & \multicolumn{3}{|c|}{$\begin{array}{c}\mathrm{NCP} \\
{\left[\mathrm{mmol} \mathrm{O} \mathrm{m}^{-2} \mathrm{~h}^{-1}\right]}\end{array}$} & \multicolumn{3}{|c|}{$\begin{array}{c}\mathrm{NCC} \\
{\left[\mathrm{mmol} \mathrm{CaCO}_{3} \mathrm{~m}^{-2} \mathrm{~h}^{-1}\right]}\end{array}$} & \multicolumn{3}{|c|}{$\begin{array}{c}\text { Nitrification } \\
{\left[\mathrm{mmol} \mathrm{N} \mathrm{m}^{-2} \mathbf{h}^{-1}\right]}\end{array}$} & \multicolumn{3}{|c|}{$\begin{array}{c}\text { Denitrification } \\
{\left[\mathrm{mmol} \mathrm{N} \mathrm{m} \mathbf{~ h}^{-1}\right]}\end{array}$} \\
\hline & \multirow{2}{*}{$\begin{array}{c}\text { mean } \\
2.16\end{array}$} & \multicolumn{2}{|c|}{$95 \% \mathrm{CI}$} & \multirow{2}{*}{$\begin{array}{c}\text { mean } \\
0.45\end{array}$} & \multicolumn{2}{|c|}{$95 \% \mathrm{CI}$} & \multirow{2}{*}{$\frac{\text { mean }}{x}$} & \multicolumn{2}{|c|}{$95 \% \mathrm{CI}$} & \multirow{2}{*}{$\frac{\text { mean }}{x}$} & \multicolumn{2}{|c|}{$95 \% \mathrm{CI}$} \\
\hline & & 0.67 & 3.65 & & 0.28 & 0.62 & & $x$ & $x$ & & $x$ & $x$ \\
\hline & -14.09 & -15.42 & -12.76 & 0.01 & -0.05 & 0.07 & 0.21 & 0.07 & 0.35 & 0.26 & 0.04 & 0.48 \\
\hline \multirow{2}{*}{ TMA } & 3.02 & 1.09 & 4.94 & 0.12 & -0.07 & 0.31 & $x$ & $x$ & $x$ & $x$ & $x$ & $x$ \\
\hline & -2.64 & -2.76 & -2.51 & -0.13 & -0.29 & 0.04 & 0.04 & 0.01 & 0.07 & 0.04 & 0.01 & 0.07 \\
\hline \multirow{2}{*}{ BES } & 0.40 & -1.28 & 2.08 & 0.45 & 0.17 & 0.73 & 0.31 & -0.27 & 0.89 & $x$ & $x$ & $x$ \\
\hline & -16.28 & -20.86 & -11.69 & -0.56 & -0.72 & -0.39 & 0.53 & -0.08 & 1.13 & 0.66 & -0.14 & 1.45 \\
\hline \multirow{2}{*}{ BCM } & 5.60 & 2.18 & 9.02 & 0.33 & 0.06 & 0.59 & $x$ & $x$ & $x$ & $x$ & $x$ & $x$ \\
\hline & -13.42 & -17.77 & -9.07 & -0.63 & -0.93 & -0.33 & 0.27 & 0.05 & 0.49 & 0.06 & -0.03 & 0.14 \\
\hline \multirow{2}{*}{ SAND } & -0.44 & -1.09 & 0.21 & -0.01 & -0.09 & 0.07 & 0.04 & 0.02 & 0.05 & 0.04 & -0.003 & 0.08 \\
\hline & -3.13 & -3.13 & -3.13 & -0.05 & -0.05 & -0.05 & 0.02 & 0.01 & 0.02 & 0.03 & 0.02 & 0.03 \\
\hline
\end{tabular}

